To cite this article: da Silva Antunes de Souza, M.C. \& Antunes de Souza, G.K. (2019). Invisible pollutants: environmental, economic and social impacts as a threat to water quality. Sostenibilidad: económica, social y ambiental, 1, 1-12. https://doi.org/10.14198/Sostenibilidad2019.1.01

\title{
Invisible pollutants: environmental, economic and social impacts as a threat to water quality
}

\author{
Contaminantes invisibles: los impactos ambientales, económicos y sociales \\ como una amenaza para la calidad del agua
}

\author{
Maria Cláudia da Silva Antunes de Souza \\ Universidade do Vale do Itajaí, Brasil \\ mclaudia@univali.br \\ https://orcid.org/0000-0002-8118-1071 \\ Greyce Kelly Antunes de Souza \\ Universidade do Vale do Itajaí, Brasil \\ greyce.kelly@univali.br \\ https://orcid.org/0000-0002-8169-1952
}

\begin{abstract}
The object of this study is a discussion on the environmental, social and economic impacts of invisible pollutants as a threat to water quality and sustainability. The investigation is geared towards contributing to effective sustainability, taking into account its threat by invisible pollutants and the fact that these pollutants are not included in routine monitoring programs of Health and Environmental bodies, nor are they incorporated to standards or legislation for environmental control. The work was then divided, and it first analyzes the importance of water quality in the attainment of sustainability. Next, it analyzes the Brazilian law on water resources; and finally, it discusses the challenges to maintain the quality of water considering the environmental, social and economic impacts of invisible pollutants. After detailed study, it is perceived that the reason for concern is that these minuscule molecules are resistant to conventional water treatment processes. They can even become increasingly toxic and pollute the noblest resource: water. For this reason, water, even after treatment, can still contain residual contaminants which, after reaching their concentration limits, become toxic and change aquatic communities. This is a critical situation, since all impacts of these molecules are still not entirely known.
\end{abstract}

Keywords: invisible pollutants; water quality; environment; sustainability. 


\section{RESUMEN}

El objeto de este estudio es abordar los impactos ambientales, sociales y económicos de los contaminantes invisibles como una amenaza para la calidad del agua y la sostenibilidad. La investigación está orientada a contribuir con la sostenibilidad efectiva, teniendo en cuenta que está amenazada por contaminantes invisibles y el hecho de que éstos no están incluidos en los programas de seguimiento de los organismos de públicos encargados de Salud y Medio Ambiente, así como tampoco están incorporados a las normas o a la legislación de control ambiental. Por ello, en primer lugar, se analiza la importancia de la calidad del agua en el logro de la sostenibilidad para, a continuación, analizar la ley brasileña sobre recursos hídricos y, finalmente, exponer los desafíos precisos para mantener la calidad del agua considerando los impactos ambientales, sociales y económicos de dichos contaminantes invisibles. Después de un estudio detallado, se percibe que el principal motivo de preocupación es que estas pequeñas moléculas son resistentes a los procesos convencionales de tratamiento de agua. Incluso pueden volverse cada vez más tóxicas y contaminar el recurso más noble: el agua. Por esta razón, el agua, incluso después del tratamiento, puede contener contaminantes residuales que, después de alcanzar sus límites de concentración, se vuelven tóxicos e intervienen en las comunidades acuáticas. Esta es una situación crítica, ya que todos los impactos de estas moléculas aún no se conocen completamente.

Palabras clave: contaminantes invisibles; agua; medio ambiente; sostenibilidad.

\section{Introduction}

The negative environmental, social and economic deterioration of water quality is reflected, among other aspects, in the loss of biodiversity, an increase in waterborne diseases, an increase in the cost of water treatment intended for domestic supply and industrial use, loss of productivity in livestock rearing and agriculture, a reduction in fish stocks, and a reduction in tourist, cultural and landscape values.

Brazilian society faces major challenges in the management of water quality, given that this is a cross-sector theme that requires a joint effort between the areas of water resources, the environment, sanitation, health, industry and agriculture. It is essential to promote reflection on the theme, through studies that will contribute to effective planning, based on measurable indicators, enabling efficient recovery and maintenance of the quality of Brazilian surface waters.

In view of this scenario, the subject of this study is a discussion of the environmental, social and economic impacts of invisible pollutants as a threat to water quality and sustainability.

The objective of this analysis is to discuss the environmental, social and economic impacts of invisible pollutants as a threat to water quality and sustainability. For this purpose, the work was divided into sections; first, it analyzes the importance of water quality for achieving sustainability. Next, it analyzes the analysis of the Brazilian legal system in relation to the water resources, and finally, it discusses the challenges of maintaining the water quality, faced with the negative environmental, social and economic impacts of invisible pollutants. This study is justified by the need to mitigate the degradation of water quality as a threat to achieving sustainability, and to review the indices for monitoring water, since conventional monitoring no longer meets the environmental needs. Moreover, there is a lack of research on the extent that the problem of water pollution can reach, bearing in mind that water pollution can even 
have trans-border implications, creating problems not only for the polluting country, but for neighboring countries too. Therefore, this is an issue that requires cross-border discussion ${ }^{1}$.

In terms of methodology, inductive logic was used, through a literature search, for use in the development of the research, including the Cartesian method for the data collection and in the final report, and the inductive method with the techniques of referent, category, operational concepts, bibliographic research, and annotation.

\section{Water: essential for achieving sustainability}

To achieve an ecologically balanced environment, proper management of the water resources is essential, since access to water is a fundamental right and an essential resource for a healthy quality of life. Among the natural resources, the importance of water is highlighted in the works of José Afonso da Silva (2011, p. 126).
Water is the most abundant simple substance of the biosphere. It exists in liquid form (salty and freshwater), solid (freshwater) and steam (freshwater), oceans and seas, polar icecaps, glaciers, lakes, rivers, groundwater, and in the atmosphere, comprising approximately 1,500 million cubic kilometers. Around $97 \%$ of water is salty, consisting of oceans and seas; $2.25 \%$ is located at the polar icecaps and in glaciers, in solid form (ice) and the remaining $0.72 \%$ is in rivers, lakes, etc.; and there is a tiny amount in the atmosphere $(0.03 \%)$. (...)
Water is a vital for human, animal and plant life. It is part of essential ecological processes, such as photosynthesis, chemosynthesis and respiration. It acts as a habitat and ecological niche for numerous animal organisms and plant species. Its mobility, power of solubility, density variation, characteristic as thermo regulator, and especially its surface tension, are attributes that account for its extraordinary ecological function (free translation).

Water is a natural resource of indispensable usefulness to society as a whole. However, it is very limited, considering its use for human consumption. Clean fresh water that is suitable and of adequate quantity is of vital importance for the survival of all living organisms, as well as for the proper functioning of ecosystems, communities and economies (ANA, 2013. p. 18). However, the quality of water resources worldwide is under increasing threat, as human populations are growing and industrial and agricultural activities are expanding, in a scenario in which climate changes can cause major changes in the hydrological cycle. Low quality water endangers human health and ecosystems, reduces the availability of drinking water and resources for other purposes, limits economic productivity, and reduces the opportunities for development.

According to the Agência Nacional de Águas - ANA [National Water Agency] (2013, p. 18), in terms of water resources, the average contribution of the Amazon River basin, in the Brazilian territory, is around $133,000 \mathrm{~m}^{3} / \mathrm{s}$ ( $73 \%$ of the country's total). Meanwhile, the contribution of water flow from foreign territories to the hydrographic region is approximately $76,000 \mathrm{~m}^{3} / \mathrm{s}$.

\footnotetext{
${ }^{1}$ Duarte, Gerusa M. Águas transfonteiriças: qualidade e questões ambientais/econômicas com interesse ao desenvolvimento sul americano. REVISTA DO INSTITUTO GEOLÓGICO USP: São Paulo. 31 (1/2), 53-65, 2010. Available at: <http://ppegeo.igc.usp.br/pdf/rig/v31n1-2/v31n1-2a04.pdf> Accessed in Feb. 2018.
} 
Table 1. Water resources of Brazil. Source: Universidade da Água, www.uniagua.or.br

\begin{tabular}{|c|c|}
\hline Region & Water Resources $(\boldsymbol{\%})$ \\
\hline North & 68.50 \\
\hline Central West & 15.70 \\
\hline South & 6.80 \\
\hline Southeast & 10.80 \\
\hline Northeast & 18.30 \\
\hline
\end{tabular}

Barros (2009, p.02) believes that because Brazil holds this significant portion of all the world's fresh water, "Brazilians have the false idea that water is an unlimited mineral resource, and that therefore, it will always be available whenever it is needed".

Low quality water endangers human health and ecosystems, reduces the availability of drinking water and resources for other purposes, limits economic productivity, and reduces the opportunities for development. There is an urgent need for the global community (public and private sectors) to unite and take up the challenge to protect and enhance the water quality of rivers, lakes, aquifers and taps. For this, greater commitment to is needed to preventing water pollution in the future, by treating contaminated waters and restoring the quality and health of rivers, lakes, aquifers, wetlands and estuaries. This will ensure that these waters meet a broader spectrum of needs of human beings and ecosystems, by adhering to the precepts of sustainability.

\subsection{Sustainability ${ }^{2}$ : a challenge for the future}

The current paradigm of humanity is sustainability. This is the desire to articulate a new society capable of perpetuating itself over time, with decent conditions. Sustainability comprises not only the relationship between economic and environmental factors, but also human equilibrium, faced with other issues (Real Ferrer, 2012. p. 319).

Until the beginning of the 1970s, the prevailing world view was that the environment is an be an inexhaustible source of resources, and that any actions to exploit the nature would be unlimited. However, phenomena such as droughts, acid rain and thermal inversion have alerted society, bringing this environmental world view into question ${ }^{3}-4$.

\footnotetext{
${ }^{2}$ Part of this research on Sustainability was developed in the work Teoria Jurídica e Transnacionalidade. SOUZA, Maria Cláudia S. Antunes; SOUZA, Greyce Kelly Antunes. SUSTENTABILIDADE E SOCIEDADE DE CONSUMO: AVANÇOS E RETROCESSOS. In: SOUZA, Maria Cláudia S. Antunes; ARMADA, Charles Alexandre Souza. TEORIA JURÍDICA E TRANSNACIONALIDADE. Vol. I. Itajaí: UNIVALI. 2014. p. 170187.

${ }^{3}$ SENADO FEDERAL. Da Conferência das Nações Unidas para o Meio Ambiente Humano, em Estocolmo, à Rio-92: agenda ambiental para os países e elaboração de documentos por Comissão Mundial sobre Meio Ambiente e Desenvolvimento. Revista em discussão. Available http://www.senado.gov.br/noticias/Jornal/emdiscussao/rio20/a-rio20/conferencia-das-nacoes-unidas-para-omeio-ambiente-humano-estocolmo-rio-92-agenda-ambiental-paises-elaboracao-documentos-comissao-mundialsobre-meio-ambiente-e-desenvolvimento.aspx. Accessed on: February 13, 2018.

${ }^{4}$ In 1972, as a consequence, the United Nations Conference on the Human Environment was held in Stockholm, and produced the Declaration on the Human Environment, establishing principles for international environmental issues, including human rights, management of natural resources, and prevention of pollution, giving rise to
} 
In 2000, to analyze the major global problems, the UN established 8 Millennium Development Goals, - MDG, which in Brazil, are called 8 Jeitos de Mudar o Mundo [8 Ways to Change the World] - and which must be met by all countries by 2015 . They are: goal 1 , to eradicate extreme poverty and hunger; goal 2 , to achieve universal primary education; goal 3 , to promote gender equality and empower women; goal 4, to reduce infant mortality; goal 5, to improve maternal health; goal 6, to combat HIV/AIDS, malaria and other diseases; goal 7, to ensure environmental sustainability; goal 8, to establish a global partnership for development ${ }^{5}$.

In relation to the Millennium Development Goals, Gabriel Real Ferrer (2008) explains that not only the seventh, but all the goals are fully relevant to the ideal of sustainability, as together, they enable social harmony:

Sustainability is more related to the Millennium Development Goals, which govern the action of humanity. The objective is to ensure the environmental conditions that make it possible for human life on the planet. In contrast, the other two aspects of sustainability, social, which has to do with inclusion, how to avoid marginalization, and incorporate new models of governance, and the economic aspects, which are related to the growth and distribution of wealth. Sustainability says that is not enough to guarantee survival, but the requirements of the human condition to ensure a dignified life ${ }^{6}$ (free translation).

According to Leonardo Boff (2012, p. 153) it is not only a matter of introducing corrective measures to the system that created the current ecological crisis, but of educating for its transformation. This means overcoming the reductionist and mechanistic view that is still prevalent, and assuming a culture of complexity.

international environmental law, raising the world political culture with respect to ecology, and serving as the first invitation for the elaboration of new economic paradigm and civilization for those countries. The Stockholm meeting led to a time of observation and global alert about environmental degradation. The Declaration of the UN Conference on the Environment described it thus: "protecting and and improving the environment for current and future generations became a key goal for humanity". Thus, the Stockholm Conference created the World Commission on Environment and Development, inaugurating the environmental agenda, and enabling the start of the relationship between the environment and development, giving the first references to Sustainable Development, which at the time was known by the term "Ecodevelopment". These were the first steps towards green thinking. In 1983, the Brundtland Report, written by the head of the World Commission on Environment and Development, gave the following concept of Sustainable Development as development that: "meets the needs of the present without compromising the ability of future generations to meet their own needs". The report adds that: "a world in which poverty and inequality are endemic will always be prone to ecological crises, among others"4, "sustainable development requires that societies meet human needs both by increasing productive potential and by ensuring equal opportunities for all". Report of the World Commission on Environment and Development. The Brundtland report "Our Common Future. Available at: http://www.un.org/documents/ga/res/42/ares42-187.htm. Accessed on: February 15, 2018.

\footnotetext{
${ }^{5}$ About the theme suggests to search in the Millennium Goals. Available at: http://www.objetivosdomilenio.org.br/. Access on February 2018.

6 "La sostenibilidad se encuentra más bien relacionada con los Objetivos del Milenio, que son la guía de acción de la humanidad. El objetivo de lo ambiental es asegurar las condiciones que hacen posible la vida humana em el planeta. En cambio, los otros dos aspectos de la sostenibilidad, los sociales que tienen que ver com la inclusión, con evitar la marginalidad, con incorporar nuevos modelos de gobernanza, etcétera, y los aspectos económicos, que tienen que ver con el crecimiento y la distribución de la riqueza. Tienen que ver con dignificar la vida. La sostenibilidad nos dice que no basta con asegurar la subsistencia, sino que la condición humana exige asegurar unas las condiciones dignas de vida". [Author's translation]. Real Ferrer, Gabriel. El derecho ambiental y el derecho de la sostenibilidad. In: PNUMA. Programa regional de capacitacion en derecho y políticas ambientales. 2008. Available at: <http://www.pnuma.org/deramb/documentos>. Accessed on: February 15, 2018.
} 
Gradually, humanity is becoming aware that it requires new values and behaviors to administer the natural laws harmoniously. Society needs a new destiny; one that is less violent, more noble, in which man distances himself from the tortuous paths, and for this, an attitude and behavioral change are needed; enabling the inter-relationships between everybody, and the ecodependence of all human beings, to become clear. For this, it is necessary to deal with environmental issues in a global and integrated way.

Freitas (2012, p. 41) asserts that sustainability:

(...) it is the constitutional principle that determines, with direct and immediate effectiveness, the responsibility of the State and society for achieving solidarity of development, both material and immaterial, socially inclusive, durable and equitable, a clean, innovative, ethical and efficient environment, in order to ensure, preferably in preventive and cautious mode, at present and in the future, the right to well-being (free translation).

Thus, worse than the human relationship with the environment is man's relationship with himself, since reaching a collective consensus on the absolute need for environmental preservation, sustainable development, and finally, sustainability, are not able to articulate a management that is able to make the measures toward these goals effective.

It is essential for humanity to be aware of the need of new values and behaviors in order to administer the natural laws in a harmonious way. Otherwise, the world's water resources will soon collapse, since the population growth, increased water consumption, and decrease in sources of drinking water on the planet will all contribute to this sad scenario. It is therefore necessary to contribute to the dissemination of knowledge, respect for the environment, the zeal for the planet's finite resources, all of which are among the objectives of sustainability.

\subsection{Resources in Brazil: legal provision}

The management of water in Brazil has been dealt with differently in different periods throughout history. From 1500 to 1940, water was considered an agricultural input; later, from 1950 to 1960, interest arose in its use in the industrial sector; from 1964 to 1985 , the environmental movement was "deemed counterrevolutionary or subversive"; after this phase, due to international pressure, a ministry for environmental causes was created, and it was only after 1995 that water management become the responsibility of the Ministry of the Environment (Barros, 2009. p. 4-6).

The legal protection of water has advanced, presenting, briefly, the following trajectory, in accordance with Almeida (2002. p. 02):

The protection of the waters, as occurred with the environment, started indirectly with the publication of economic and health regulations, as well as treatment linked to the right to property and neighborhood (Brazilian Civil Code); it was raised to the category of a legally protected asset, and deserving of its own legislation (Código das Águas Water Code). In a second phase, the reception of the environmental issue by the legal system was based on the utilitarianism of the assets; the fragmentation of the object 
protected, and the legislative apparatus. Finally, the need was recognized to protect the waters within the global environmental structure, based on an integrated management of the water resources with the environment, with a view to sustainable development and the maintenance of an ecologically balanced environment, as recognized by the CRFB. The turning point in the protection of water resources was the promulgation of the 9,433/97 - Lei das Águas (Water Act) (free translation).

It is recorded that even at the beginning of the last century, it can be affirmed that the legal professionals viewed the problem of fresh water as something limited to neighborhood disputes or its use for electrical energy. Even under the regulation of the Water Code of 1934, the focus given to the theme was always more from a perspective of private law rather than of public law. It is reiterated that the change in treatment only came with the Constitution of the Federative Republic of Brazil (1988), with the implementation of this new order becoming consecrated with the promulgation of Law 9,433/97, which instituted the National Policy on Water Hydric Resources $^{7}$ and created the National System for the Management of Water Resources (FREITAS. 2008. p. 19).

Finally, Law 9,984 of July 17, 2000 was published, which instituted the National Water Agency, the federal entity responsible for implementing the National Policy on Water Resources, and for coordinating the National Management System of these resources (ANA, 2013, p. 18).

It is important to emphasize that some changes were defined at administrative level, through CONAMA resolutions 20/86 and 06/87; the first deals with the classification of fresh water, brackish water and salt water of the national territory, defining the quality standards for each of these classes, according to the main uses designated for them; the second regulates environmental licensing of concession-holders for the exploration, generation and distribution of energy, and finally, no. 06/90, which regulates the production, importation, marketing and use of chemical dispersants used to control oil spills.

Although Brazil has a good legal framework to regulate its water resources, there is still inefficiency in complying with the current legislation for management and monitoring, considering that the instruments used as indicators of water quality do not contemplate the presence of various substances that are harmful to the environment.

\footnotetext{
${ }^{7}$ Created as a consequence of Law 9,443/97, known as the Lei das Águas [Water Act], the National Water Agency (ANA) has institutional and operational characteristics that differ slightly from those of other regulatory agencies. The law gave the Federal Executive Authorities the task of implementing the National System for the Management of Water Resources (Singreh) and the National Policy on Water Resources (PNRH). In addition, it created an authority responsible for issuing rights to use the water resources in rivers within the national territory, i.e. those that cross more than state, or those that border with other countries. To this end, Law 9,984/2000 created the ANA, which since then, has adopted actions directly or indirectly related to regulatory activities. The PNRH established five management instruments: plans for the water resources; the classification of water bodies, according to their prevalent uses; the granting of rights to use the water resources; charging for the use of water resources, and the Information System on Water Resources (Snirh). [BRASIL. O Balanço das Águas é uma revista anual que resume as principais atividades da Agência Nacional de Águas - V. 1 n. 1 - Financial year 2011].
} 


\section{The challenges of maintaining water quality in light of the negative environmental, social and economic impacts of invisible pollutants}

A broad spectrum of human and natural processes affects the biological, chemical and physical characteristics of water, impacting their quality. Various human activities, such as agriculture, industry, mining, human waste disposal, population growth, urbanization and climate change, have an impact on water quality. Agriculture can cause contamination by nutrients and pesticides and increasing the salinity of the water. Contamination caused by excess nutrients has become one of the most widespread problems worldwide in terms of water quality, and it is estimated that the application of agrochemicals is already at more than two million tons per year. Each year, industrial activities throw between three hundred and four hundred million tons of heavy metals, solvents, toxic sludge and other effluents and solid wastes into the world's water systems (ANA, 2013. p. 22).

Human activities, as well as natural processes, can change the physical, chemical and biological characteristics of the water, with specific implications for human health and the ecosystem. Water quality is affected by changes in levels of nutrients, sediment, temperature, $\mathrm{pH}$, heavy metals, non-metallic toxins, persistent organic and agrotoxic components, and biological factors, among many others. (CARR, 2008).

Each year, more people die due to the consequences of unsafe water than through from all forms of violence, including wars, with children under five years of age being the most impacted. Unfit or inadequate water, and the lack of treatment and adequate provision of domestic sewage and hygiene, are the causes of approximately 3.1 per cent of all deaths - more than 1.7 million per year - and 3.7 per cent of years of lost life due to health problems considered as having the highest impact worldwide (ANA, 2013. p. 18).

It is known that a wide range of other organic and inorganic contaminants also have direct and indirect impacts on human health. Metals such as mercury, copper and zinc occur naturally in the environment and at low concentrations, are essential for the proper functioning of the ecosystem and human health. However, prolonged exposure to high levels of these metals can have serious consequences for human, as they tend to bioaccumulate in the bodily tissues (ANA, 2013. p. 43).

In 1962, in the work Primavera Silenciosa, Carson (2010, p. 29) was already warning about the use of chemical pesticides and pollution to the environment. The author states that: "Synthetic pesticides enter and remain in the bodies of fish, birds, reptiles and wild and domestic animals in universal form. They have been found in nearly all the major river systems and even in underground water courses flowing unseen through the Earth.

For the most part, this pollution is invisible, revealing its presence when hundreds or thousands of fish die, but more commonly, it is never detected. The chemicals used to ensure water purity do not have routine tests for these organic pollutants, nor any method to remove them, as was observed by Carson (2010, p. 49).

The current treatment system is still not prepared to detect and eliminate many of these harmful elements to the quality of water, and it is necessary to develop, invest and employ more specific treatment and complex techniques, otherwise, the environment will continue to suffer serious and irreversible damage. 
Through the development of more sensitive methods, chemical substances, previously unknown, have begun to be detected, identified and defined in terms of their potential risks to the environment. This is the case of the so-called "invisible" contaminants, i.e. compounds used for decades, but which have only recently been assessed and monitored (PEDROSO, 2007. p. $34)$.

The term " invisible or emerging pollutant" can be used to define a special group of substances with peculiar characteristics due to its increasing level of use by society and their real potential for contamination, because they do not need to persist in the environment to cause negative effects (REIS FILHO, 2007. p. 283-288). Invisible pollutants are any chemical compound present in a variety of commercial products such as medicinal products for veterinary use, food packaging, hygiene products, and pesticides released directly into water bodies or the sewerage network.

Invisible pollutants are of different classes of compounds, with large-scale applications, such as drugs (antibiotics, anti-inflammatories, analgesics and lipid regulators); beauty products (suntan lotions, antiseptics, insect repellents and fragrances); industrial chemicals (plasticizers, wood preservatives, cleaning products, anticorrosives, and gasoline additives); hormones and steroids; and pesticides (Abreu, 2015).

In most cases, these compounds are not degraded by conventional methods of treatment (biological processes); thus, even after passing through treatment plants, they remain in free form in the environment, and can reach human drinking water. Potential risks to human health and the environment include dysfunctions in the endocrine and reproductive systems of humans and animals, miscarriages, metabolic disorders, and malignant cancers, as well as the induction of more resistant bacteria (REIS FILHO, 2007. p. 283-288). Due to the exposure of some aquatic species to these substances, morphological changes and extinction of certain species have been recorded (ARIAS, 2015).

These chemicals are increasingly present in the world's water systems, and when they reach the environment, they cause damage to the ecosystem and human health. Their propagation in seas, rivers and reservoirs is a result of the growth of cities and new industrial processes (ARIAS, 2015). However, it is time to take a global stance, faced with the challenge of protecting and improving the quality of the planet's water reserves, preventing pollution; treating polluted water, and even eliminating invisible pollutants and restoring ecosystems, mitigating the environmental impacts caused by the action of man.

\section{Conclusions}

The management of water quality is one of the major challenges facing society and requires a joint effort between the areas of water resources, environment, sanitation, health, industry and agriculture. It is essential to establish an effective planning, based on measurable indicators that will enable efficient recovery and the maintenance of the quality of surface waters.

Waters designated as potable and used by the population, are contaminated by a type of pollutant that is invisible to the naked eye, difficult to detect, has serious consequences, and is not regulated in Brazil. This constitutes a major concern, as it is present in domestic sewage, which unlike industrial effluents, does not have a high concentration of a particular compound, 
but lower concentrations of different compounds, making it more complex to understand and treat.

The instruments and tools used do not match the current reality for the proper management of water resources, bearing in mind the gaps and failures since their elaboration and implementation, through to the joint functioning of powers at the different levels.

Low quality water endangers human health and ecosystems, reduces the availability of drinking water and resources for other purposes, limits economic productivity, and reduces the opportunities for development.

While there are treatment technologies that produce water that only just meets the current regulatory standards, these do not ensure the proper removal of many invisible contaminants, including antibiotics and hormones; the supply system of purified water is at risk, causing serious damage to the environment. The problem of invisible pollutants is far from resolved, and the environmental consequences are unpredictable. There have been studies on the potential carcinogenic effects and endocrine deregulation directly affecting living beings.

These contaminants are not included in routine monitoring programs the Environmental and health bodies; neither are they inserted in the norms or legislation for environmental control. This situation is critical because, we do not yet know all the impacts on the Environment, especially in the long term.

\section{References}

Abreu, Fernando Girardi de \& Brandão, João Luiz Boccia. (2018). Impactos e desafios futuros no monitoramento dos contaminantes emergentes. XX Simpósio Brasileiro de Recursos Hídricos. Retrieved from https://www.abrh.org.br/sgcv3/UserFiles/Sumarios/a8514ef31d822864a33bf9d119d91 095_9148e05313c2aa67326457f676c03fbf.pdf

Almeida, Caroline Corrêa de. (2002). Evolução histórica da proteção jurídica das águas no Brasil, p. 2. Retrieved from http://jus.com.br/artigos/3421

Arias, David Gutierrez. (2013). Contaminantes emergentes, seus efeitos no meio ambiente e desafios para novos mecanismos de purificação de água. Retrieved from http://www.ib.unicamp.br/dep_biologia_animal/sites/www.ib.unicamp.br.dep_biologi a_animal/files/CONTAMINANTES\%20EMERGENTES\%20PURIFICA\%C3\%87\%C 3\%830\%20\%C3\%81GUA.PDF

Barros, Airton Bodstein de \& Barros, Angela Maria Abreu de. (2009). A difícil aplicabilidade da política de águas no Brasil. Inter Science Place - Revista Científica Internacional, 2 (7).

Boff, Leonardo. (2012). Sustentabilidade: o que é, o que não é. Petrópolis, RJ: Vozes.

Brasil. Agência Nacional de Águas (ANA). (2013). Cuidando das águas: soluções para melhorar a qualidade dos recursos hídricos. Brasília: Agência Nacional de Águas, Programa das Nações Unidas para o Meio Ambiente. 
Brasil. Agência Nacional de Águas (ANA). (2018). Retrieved from http://www2.ana.gov.br/Paginas/acessoainformacao/default.aspx

Brasil. Agência Nacional de Águas (ANA). (2011). O Balanço das Águas é uma revista anual que resume as principais atividades da Agência Nacional de Águas, 1 (1).

Brasil. Agência Nacional de Águas (ANA). (2018). Retrieved from http://www.ana.gov.br

Brasil. Senado Federal. Da Conferência das Nações Unidas para o Meio Ambiente Humano, em Estocolmo, à Rio-92: agenda ambiental para os países e elaboração de documentos por Comissão Mundial sobre Meio Ambiente e Desenvolvimento. Revista Em Discussão. $\quad$ Retrieved from http://www.senado.gov.br/noticias/Jornal/emdiscussao/rio20/a-rio20/conferencia-dasnacoes-unidas-para-o-meio-ambiente-humano-estocolmo-rio-92-agenda-ambientalpaises-elaboracao-documentos-comissao-mundial-sobre-meio-ambiente-edesenvolvimento.aspx

Carson, Rachel. (2010). Primavera Silenciosa. Trad. por Claudia San’t Anna Martins. São Paulo: Gaia.

Carr, G.M. \& Neary, J.P. (2008). Water Quality for Ecosystem and Human Health, 2nd Edition. United Nations Environment Programme Global Environment Monitoring System. Retrieved from http://www.gemswater.org/publications/ pdfs/water_quality_human_health.pdf

Duarte, Gerusa M. (2010). Águas transfonteiriças: qualidade e questões ambientais/econômicas com interesse ao desenvolvimento sul americano. Revista do Instituto Geológico USP, 31 (1/2), 53-65. Retrieved from http://ppegeo.igc.usp.br/pdf/rig/v31n1-2/v31n12a04.pdf

Freitas, Juarez. (2012). Sustentabilidade: direito ao futuro, 2nd Edition. Belo Horizonte: Fórum.

Freitas, Vladimir Passos de. (2008). Águas. Aspectos jurídicos e ambientais. Curitiba: Juruá.

Silva, José Afonso da Silva. (2011). Direito Ambiental Constitucional. São Paulo: Malheiros.

Souza, Maria Cláudia S. Antunes \& Souza, Greyce Kelly Antunes. (2014). Sustentabilidade e Sociedade de Consumo: Avanços e Retrocessos. In: Maria Cláudia S. Antunes Souza \& Charles Alexandre Souza Armada. Teoria Jurídica e Transnacionalidade Vol. I. Itajaí: UNIVALI.

Pedroso, R.C.R. (2007). Desenvolvimento de Métodos de Análise por CLAE-UV para os antimicrobianos tetraciclina, sulfametoxazol e trimetoprima utilizando materiais à base de sílica e poliméricos como sistemas de pré-concentração (Unpublished master's thesis). Instituto de Química, Universidade Federal do Rio Grande do Sul, Porto Alegre, Brasil. 
Real Ferrer, Gabriel. (2012). Calidad de vida, medio ambiente, sostenibilidad y ciudadanía. Construimos juntos el futuro. Revista NEJ - Eletrônica, 17 (3), 319-321. Retrieved from www.univali.br/periodicos

Real Ferrer, Gabriel. (2008). El derecho ambiental y el derecho de la sostenibilidad. In: PNUMA. Programa regional de capacitación en derecho y políticas ambientales. Retrieved from http://www.pnuma.org/deramb/documentos

Reis Filho, R.W., Luvizotto-Santos, R. \& Vieira, E.M. (2007). Poluentes Emergentes como Desreguladores Endócrinos. Journal of the Brazilian Society of Ecotoxicology, 2.

United Nations Department of Economic and Social Affairs (DESA). (1987). Relatório Brundtland, Report of the World Commission on Environment and Development 42/187. Retrieved from http://www.un.org/documents/ga/res/42/ares42187.htm

United Nations Development Programme. Objetivos do Milênio. Retrieved from http://www.br.undp.org/content/brazil/pt/home/presscenter/articles/2019/o-mundodeve-acelerar-e-aprofundar-os-esforcos-para-alcancar-os-.html 